Proc. Estonian Acad. Sci. Eng., 2003, 9, 2, 91-106

\title{
Observed thermohaline fields and low-frequency currents in the Narva Bay
}

\author{
Janek Laanearu $^{\mathrm{a}}$ and Urmas Lips ${ }^{\mathrm{b}}$ \\ a Department of Mechanics, Tallinn Technical University, Ehitajate tee 5, 19086 Tallinn, Estonia; \\ janeklaanearu@hotmail.com \\ b Faculty of Marine Sciences, Estonian Maritime Academy, Luise 1-3, 10142 Tallinn, Estonia \\ Received 12 July 2002, in revised form 10 March 2003
}

\begin{abstract}
This article analyses hydrophysical processes in the Narva Bay, a sub-basin of the Gulf of Finland, on the basis of measurements collected during April-August 2001. The fields of temperature and salinity are determined from the measurement data, and the progressive-vector diagrams are constructed for the currents. Surface-water characteristics and spreading of the Narva River water were affected by the winds. Large vertical displacements of the coastal waters associated with the Ekman transport away from the shore were observed in the western part of the bay. The currents at the buoy stations revealed the signals of near-inertial fluctuations in the surface layer. Theoretical analysis of low-frequency motions is based on the integrated Ekman equations, which use the wind stress and include the Rayleigh friction. The bursts of the inertial oscillations in the mixed layer observed in the open-sea side of the bay during strong winds are qualitatively well reproduced by numerical calculations.
\end{abstract}

Key words: Gulf of Finland, Narva Bay, temperature, salinity, Ekman transport, inertial oscillation.

\section{INTRODUCTION}

The Narva Bay is a large sub-basin on the southern coast of the Gulf of Finland. The bay has an open boundary in the NW side, with its bottom varying between 0 and 50 metres (Fig. 1). The SW coast of the bay is a part of the sedimentary rock, the cliff of which rises along a shore of the Gulf of Finland, towering up for 56 metres over the sea level. The largest freshwater source for the bay is the Narva River, which originates from the Lake Peipsi (the fourth largest lake in Europe) and flows through the Narva water reservoir where it is joined by the Pljussa River inflow. The Rosson River connects the Narva River with the Luga River downstream of the municipal water reservoir. A long-term 


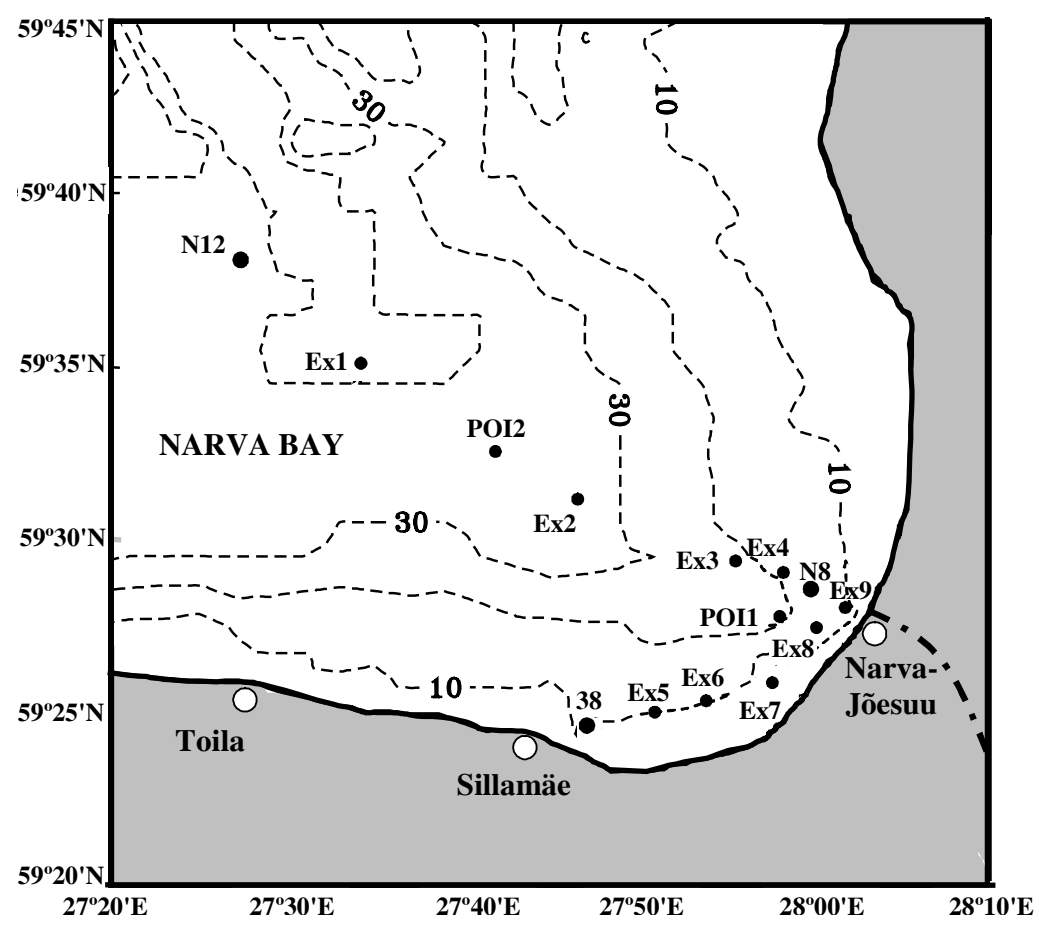

Fig. 1. Stations in the Narva Bay (shown by dots). The dash-dot line indicates Narva River bed.

mean of the Narva River volume flux is around $400 \mathrm{~m}^{3} \mathrm{~s}^{-1}$, but this magnitude can be significantly larger during floods $\left[{ }^{1}\right]$. The inflow from the large river regulates the thermohaline characteristics as well as the nutrients concentration in the coastal sea $\left[{ }^{2}\right]$.

The measurements in the western part of the Narva Bay during April-August 2001 focused on an intensive study of water stratification and surface-layer currents. In particular, the thermohaline and dynamical fields in the vicinity of the Narva River mouth as well as in the coastal and open-sea areas were covered. In different days, with the periodicity of a week or more, 58 snapshots of CTD (conductivity, temperature, depth) profiles at stations $\mathrm{N} 8\left(59^{\circ} 28.5^{\prime} \mathrm{N}\right.$, $\left.28^{\circ} 00.5^{\prime} \mathrm{E}\right), \mathrm{N} 12\left(59.38 .0^{\prime} \mathrm{N}, 27^{\circ} 26.9^{\prime} \mathrm{E}\right), 38\left(59.24 .4^{\prime} \mathrm{N}, 27^{\circ} 47.0^{\prime} \mathrm{E}\right)$, near moorings POI1 $\left(59^{\circ} 27.9^{\prime} \mathrm{N}, 27^{\circ} 56.9^{\prime} \mathrm{E}\right) \&$ POI $2\left(59^{\circ} 32.8^{\prime} \mathrm{N}, 27^{\circ} 40.5^{\prime} \mathrm{E}\right)$, and at extra stations Ex1-Ex9 were collected (Fig. 1). The vertical profiles of the seawater temperature and salinity were measured using a portable CTD probe SeaCat (SBE-19, SeaBird Instruments Ltd). The quality of the used CTD probe was checked by the high precision Guidline Instruments Ltd salinometer AUTOSAL in the Estonian Marine Institute Laboratory. The rotor-type current meters, Aanderaa instruments RCM-7 $\left[{ }^{3}\right]$, were deployed in the surface layer of the Narva Bay. One current meter was installed in the vicinity of the Narva River mouth for periods of two and five weeks, whereas the other in the open-sea side 
of the bay for a period of six weeks. During the surveys, water samples from stations N8, N12, and 38 were collected for the chemical-biological analyses. Atmospheric conditions were observed at the meteorological stations in NarvaJõesuu and in Kunda, around $80 \mathrm{~km}$ westward. The air temperature and the wind speed as well as the wind direction were measured at the height of $10 \mathrm{~m}$ above the ground. The Estonian Meteorological and Hydrological Institute provided us with the meteorological data.

This study concentrates on observational results and simple analysis of wind induced motions in the bay. In Section 2, meteorological parameters are analysed with emphasis mainly on the wind conditions in Narva-Jõesuu and Kunda. Section 3 deals with direct interpretations of the observed stratification situations in the bay. In Section 4, current measurements at buoy stations are used to describe circulation in the surface layer. In Section 5, the Ekman problem is evaluated on the basis of the observed wind and hydrophysical parameters. Finally, the physical processes related to the changes of the thermohaline fields and the low-frequency motions in the Narva Bay are discussed.

\section{METEOROLOGICAL PARAMETERS}

The weather conditions during the field measurements in the Narva Bay were variable. Air temperature changed from $-1{ }^{\circ} \mathrm{C}$ (spring minimum) to $+30^{\circ} \mathrm{C}$ (summer maximum) in Narva-Jõesuu and Kunda. At the end of April and the beginning of May, air temperature occasionally increased over $+20^{\circ} \mathrm{C}$, which represents comparatively warm weather conditions in NE Estonia $\left[^{4}\right]$. During the same period, the night temperature in spring dropped below $0^{\circ} \mathrm{C}$. However, summer months were characterized by warm and rather calm weather, which favored our field work in the Narva Bay.

Wind recordings were saved as 10-minute averages and gusts, both with a time step of three hours; thus eight vectors characterize wind change per day. The measured wind speed and direction have discretization of $1 \mathrm{~m} \mathrm{~s}^{-1}$ and $10^{\circ}$, respectively. According to the Narva-Jõesuu measurements during the AprilSeptember period, weak winds $\left(<5 \mathrm{~m} \mathrm{~s}^{-1}\right)$ blew mostly from ESE. Figure 2 shows the distribution of stronger winds, the speed of which was $5 \mathrm{~m} \mathrm{~s}^{-1}$ and higher. Comparatively strong winds $\left(>7 \mathrm{~m} \mathrm{~s}^{-1}\right)$ existed from NNE and $\mathrm{W}$. The westernsector winds dominated also within the moderate speed range $\left(5-7 \mathrm{~m} \mathrm{~s}^{-1}\right)$. The strong winds of $8-10 \mathrm{~m} \mathrm{~s}^{-1}$ are also listed in Table 1. (Note that the gusts exceeded the 10-minute average speeds of strong winds up to two times and weak winds up to five times.) In July-August, only weak and moderate winds existed, since the SW wind at the maximum speed of $7 \mathrm{~m} \mathrm{~s}^{-1}$ within 1-3 August was the strongest of the observed.

During April-September 2001, the winds in Kunda, characterized with a speed over $7 \mathrm{~m} \mathrm{~s}^{-1}$, blew from NNE and from the southern sectors. Among the moderate speed range, the winds from the southern sectors dominated. Figure 3 shows the distribution of the strong and moderate winds. The weak winds with a 


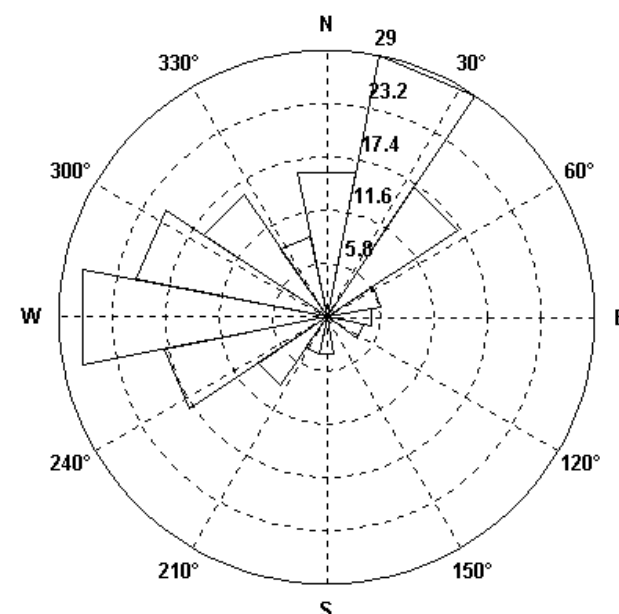

Fig. 2. Rose of the strong and moderate winds $\left(>4 \mathrm{~m} \mathrm{~s}^{-1}\right)$ recorded in Narva-Jõesuu during April-September 2001. Strong winds $\left(>7 \mathrm{~m} \mathrm{~s}^{-1}\right)$ are from NNE and $\mathrm{W}$. The moderate winds blew predominantly from the western sectors.

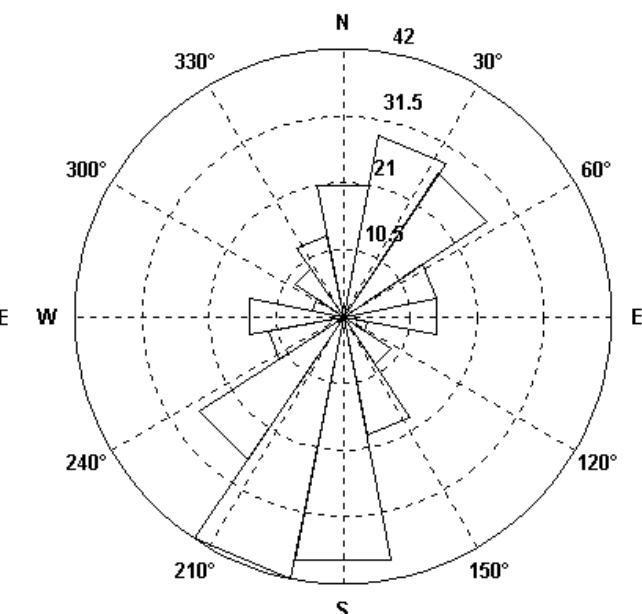

Fig. 3. Rose of the strong and moderate winds $\left(>4 \mathrm{~m} \mathrm{~s}^{-1}\right)$ recorded in Kunda during AprilSeptember 2001. Strong winds $\left(>7 \mathrm{~m} \mathrm{~s}^{-1}\right)$ blew from NNE and from the southern sectors. The moderate winds exist predominantly in the southern sectors.

Table 1. Events of strong winds in Narva-Jõesuu and Kunda

\begin{tabular}{l|c|c|c|c}
\hline \multirow{2}{*}{ Date } & \multicolumn{2}{|c|}{ Narva-Jõesuu } & \multicolumn{2}{c}{ Kunda } \\
\cline { 2 - 5 } & Direction & Speed, $\mathrm{m} \mathrm{s}^{-1}$ & Direction & Speed, $\mathrm{m} \mathrm{s}^{-1}$ \\
\hline 13-14 April & NNE & $\mathbf{1 0}$ & NNE & $\mathbf{1 2}$ \\
16 April & SSW & 7 & SW & $\mathbf{8}$ \\
2 May & WSW & $\mathbf{8}$ & W & 5 \\
4 May & S & 7 & SSW & $\mathbf{8}$ \\
6 May & NNE & $\mathbf{8}$ & NNE & 7 \\
20 May & SW & $\mathbf{8}$ & W & $\mathbf{8}$ \\
22 May & N & 6 & N & $\mathbf{8}$ \\
25 May & WNW & $\mathbf{8}$ & WNW & 5 \\
14 June & W & $\mathbf{9}$ & WNW & $\mathbf{8}$ \\
22-24 June & NE & $\mathbf{9}$ & NE & 7 \\
11 July & S & 4 & SSW & $\mathbf{8}$ \\
19 July & S & 3 & SSE & $\mathbf{1 0}$ \\
28 July & NW & 5 & NNE & $\mathbf{8}$ \\
30 July & S & 5 & SW & $\mathbf{8}$ \\
2 August & WSW & 6 & NNW & $\mathbf{8}$ \\
22 August & WNW & 4 & NE & $\mathbf{8}$ \\
28 August & E & 6 & SE & $\mathbf{8}$ \\
24-25 September & NNE & $\mathbf{8}$ & NE & $\mathbf{1 2}$ \\
29 September & W & $\mathbf{8}$ & NNW & $\mathbf{9}$
\end{tabular}




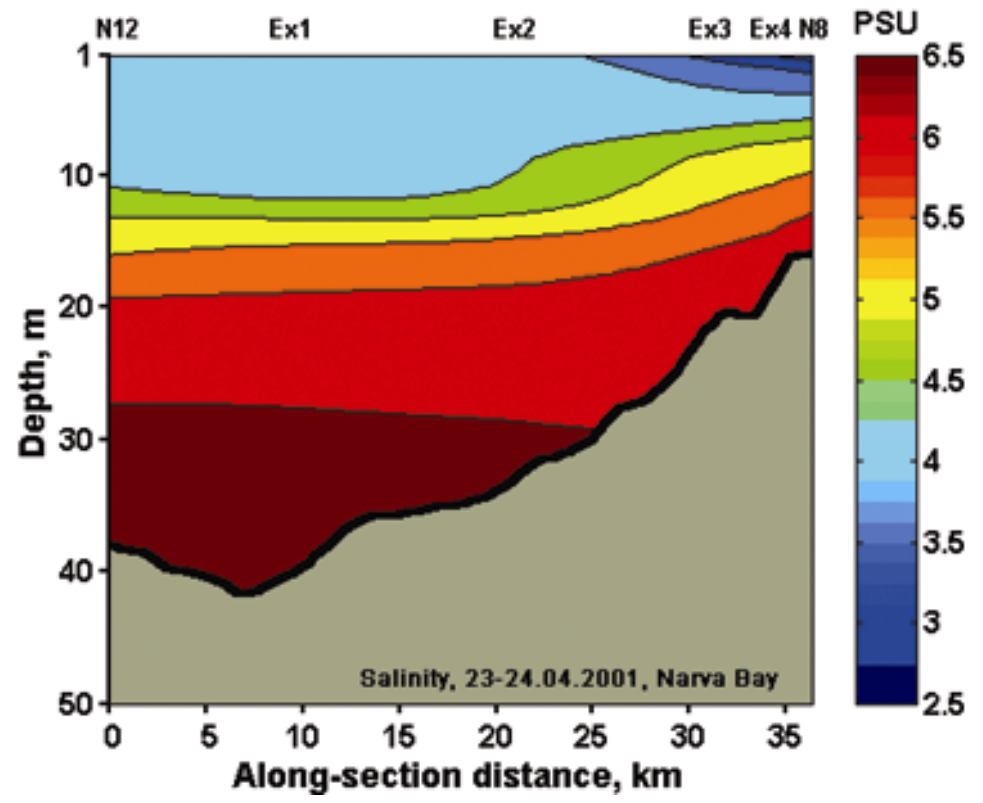

Fig. 4. Salinity transect in the Narva Bay in April 2001. Stable stratification with the less saline water above the more saline water.

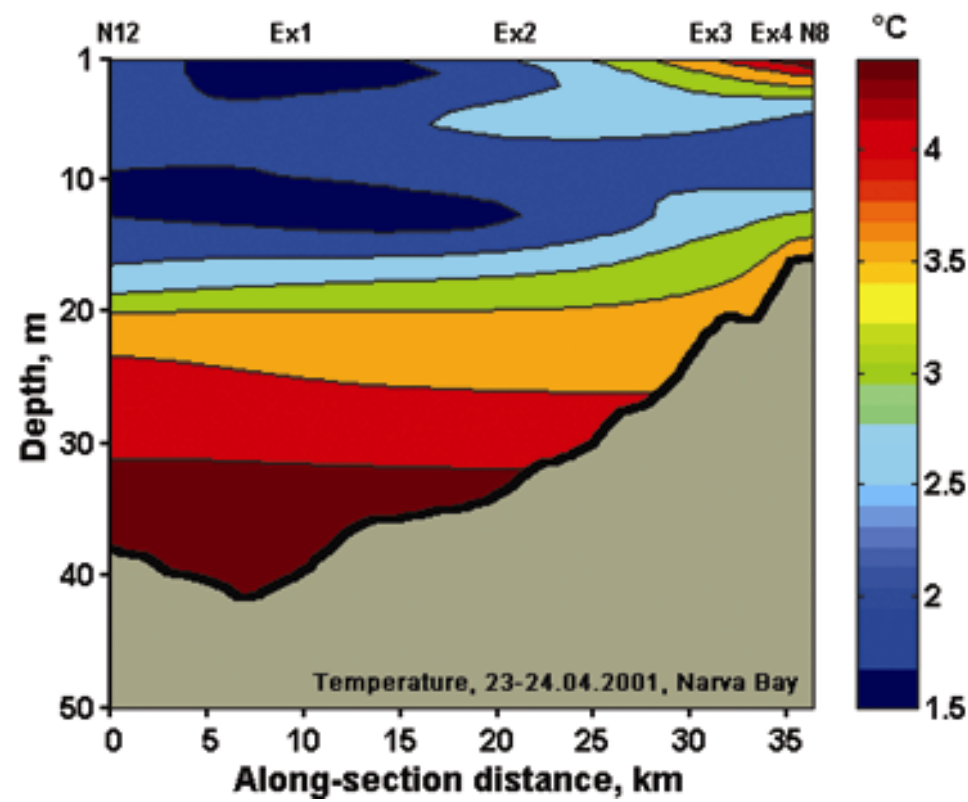

Fig. 5. Temperature transect in the Narva Bay in April 2001. It shows the stratification with the colder water above the slightly warmer water. 


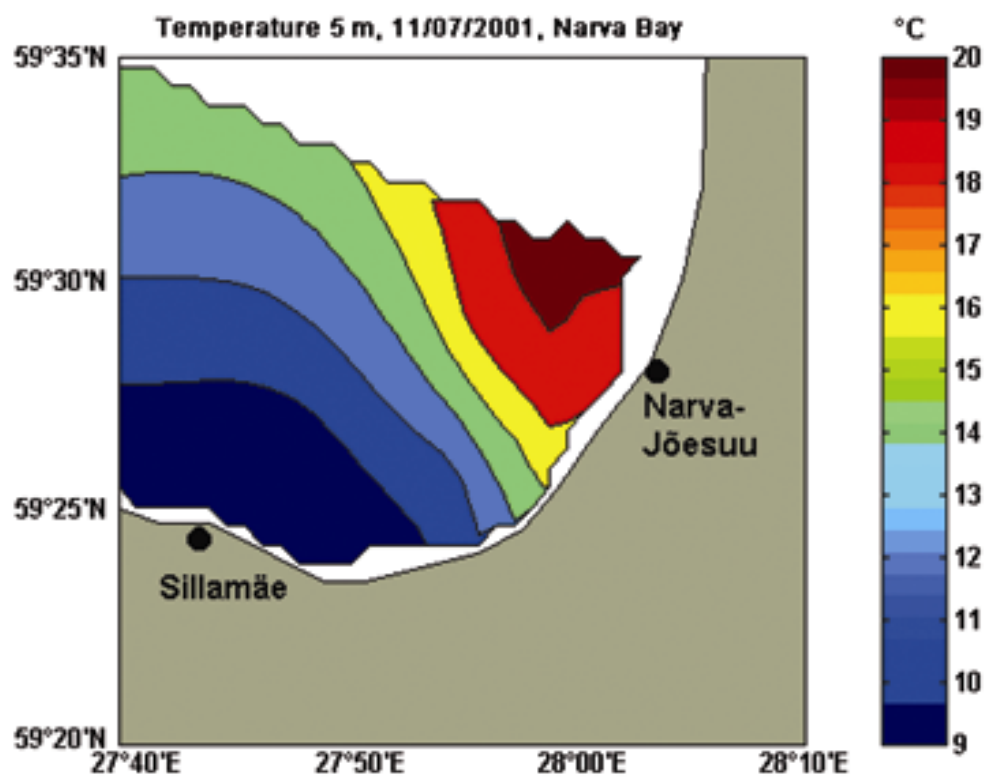

Fig. 6. Horizontal distribution of the temperature at $5 \mathrm{~m}$ depth in the Narva Bay observed on 11 July 2001. Temperature is comparatively high near the Narva River mouth, but close to the Sillamäe shore surface water is replaced with the Narva Bay deep water, indicating upwelling. 
speed less than $5 \mathrm{~m} \mathrm{~s}^{-1}$ were quite dispersive by directions, but the south-north airflows prevailed (which evidently corresponded to the summer sea breeze). The occurrence of the westerly winds was rather infrequent, but some storms existed. The strong winds in Kunda were characterized with speeds of $8-12 \mathrm{~m} \mathrm{~s}^{-1}$ and are listed in Table 1. The Kunda winds in July-August were comparatively stronger in their magnitude than those in Narva-Jõesuu. Thus, the Kunda measurements, by and large, should represent better the forcing conditions in the open-sea side of the Narva Bay.

We have used different classification of winds, since traditionally in meteorology, the speed of weak winds is $0-5 \mathrm{~m} \mathrm{~s}^{-1}$, of moderate winds $6-10 \mathrm{~m} \mathrm{~s}^{-1}$, and of strong winds higher than $10 \mathrm{~m} \mathrm{~s}^{-1}$. The direct analysis of the data from the meteorological stations revealed good directional correlation between the winds that exceed the speed $7 \mathrm{~m} \mathrm{~s}^{-1}$, but the wind speed was comparatively lower in Narva-Jõesuu (Table 1). According to the analysis of 15-year long meteorological data in $\left[^{5}\right]$, the strongest winds on the western coast of Estonia blow either from the southern sectors or from NNW. This result corresponds approximately to the measured distribution of strong and moderate winds in Kunda. Nevertheless, Narva-Jõesuu winds might represent also a specific regime in the eastern part of the Gulf of Finland.

\section{THERMOHALINE CHARACTERISTICS}

The Narva Bay has open boundaries to the north as well as to the west, implying that the water exchange between the bay and the rest of the Gulf of Finland is topographically not restricted. Moreover, the more or less smooth north-westward deepening of the bay bottom allows relatively free deep-water intrusion from the Gulf of Finland interior. The influence of the largest freshwater source of the bay, the Narva River, on stratification is certainly related to the flux rate and wind conditions. Usually, riverwater outflow forms a plume, which spreads over ambient coastal water and exhibits strong vertical stratification. In the open-sea conditions, the surface-water mixing is essentially dependent on the strong wind as well as on its variations $\left.{ }^{6}\right]$. However, also the winds can be responsible for penetration of the river plume away from the coast. The short wind waves on the sea surface can mainly magnify the turbulent diffusion of freshwater into deeper layers $\left[^{7}\right]$.

Altogether twelve surveys were organized and rather different stratification situations were observed in the Narva Bay. On 23-24 April, a cruise to the Gulf of Finland, special CTD casts between stations N12 and N8 were conducted. Stations N12, Ex1, Ex2, Ex3, Ex4, and N8 in Fig. 1 are located perpendicular to the coast (close to the Estonian-Russian marine borderline), at distances of 1-6 nmi. The observed temperature and salinity structures demonstrated expressively the "cold-season" situation, where the less saline and relatively cold water mass lies above the more saline and slightly warmer water mass. Plots in 
Figs. 4 and 5 show that water with salinity less than 5 PSU and the temperature less than $3{ }^{\circ} \mathrm{C}$ is locked between the sea surface and depths of $5-15 \mathrm{~m}$. The bottom water in the Narva Bay was characterized by salinity around 6 PSU and by the temperature higher than in the surface layer. In Figs. 4 and 5, a fresh- and warm-water intrusion, originating from the Narva River, is also clearly seen. The upper mixed-layer depth in the Narva Bay was comparatively thicker in the opensea side of the bay.

An interesting stratification situation was observed on 10 May, during the engine-dinghy cruise. Special CTD measurements were performed between stations 38 and N8, parallel to the coast of the bay. In Fig. 1, stations 38, Ex5, Ex6, Ex7, Ex8, and N8 are located approximately along the $10 \mathrm{~m}$ isobath, having distances of about $2 \mathrm{nmi}$. The water column close to the river-mouth area was stratified, but the water near Sillamäe was practically homogeneous. (The wind induced coastally-trapped internal waves usually create mixing along the shore of the shallow sea $\left[^{8}\right]$.) Also, the Narva River water "advection-diffusion" along the SW coast of the bay was evident, since a comparatively warm $\left(9.5^{\circ} \mathrm{C}\right)$ and less saline (3.5 PSU) water mass existed westward of the river mouth.

A stratification situation in the coastal zone, apparently formed independently of the freshwater source, was observed during a cruise on 11 July 2001. The horizontal distribution of temperature at $5 \mathrm{~m}$ depth is shown in Fig. 6. The temperature is relatively high near the Narva River mouth, but westward surface water is replaced with water from the Narva Bay deep layer, since the coastalwater temperature near Sillamäe was around $10^{\circ} \mathrm{C}$. The particular thermohaline situation was associated with specific atmospheric conditions, since two days before this cruise (on 11 July) the moderate eastern sector winds changed to a stronger SW wind, according to the measurements in Kunda (Table 1). The strengthened along-shore component of the wind can be the reason why the surface water moved towards the open sea due to the Ekman transport, a process that finally led to an upwelling near the Sillamäe coast. Nevertheless, the upwelling process cannot be a purely local response to the wind, since large vertical displacements of the coastal waters can be transformed to the internal waves when the atmospheric conditions are suitable $\left[{ }^{9}\right]$. This observed upwelling event is important also from the environmental aspects, because usually with the upwelled water nutrients are brought into the euphotic zone, and the growth of microorganisms is favoured.

During April-August 2001, the surface-water temperature in the Narva Bay, averaged over $10 \mathrm{~m}$ depth (or until bottom in the shallow area), varied between 2 and $22^{\circ} \mathrm{C}$ (Fig. 7a). The upper-layer water was relatively cold during the spring months, but from the beginning of July, the temperature was around $20^{\circ} \mathrm{C}$. The average salinity of the surface water in the bay revealed rather irregular variations as compared to a clear seasonal pattern (Fig. 7b). Interesting thermohaline conditions are represented in Fig. 7. During June and July the depth-averaged salinity did not vary significantly over the bay area, but the averaged temperature was rather disperse, while in August the thermohaline situation was the opposite. 

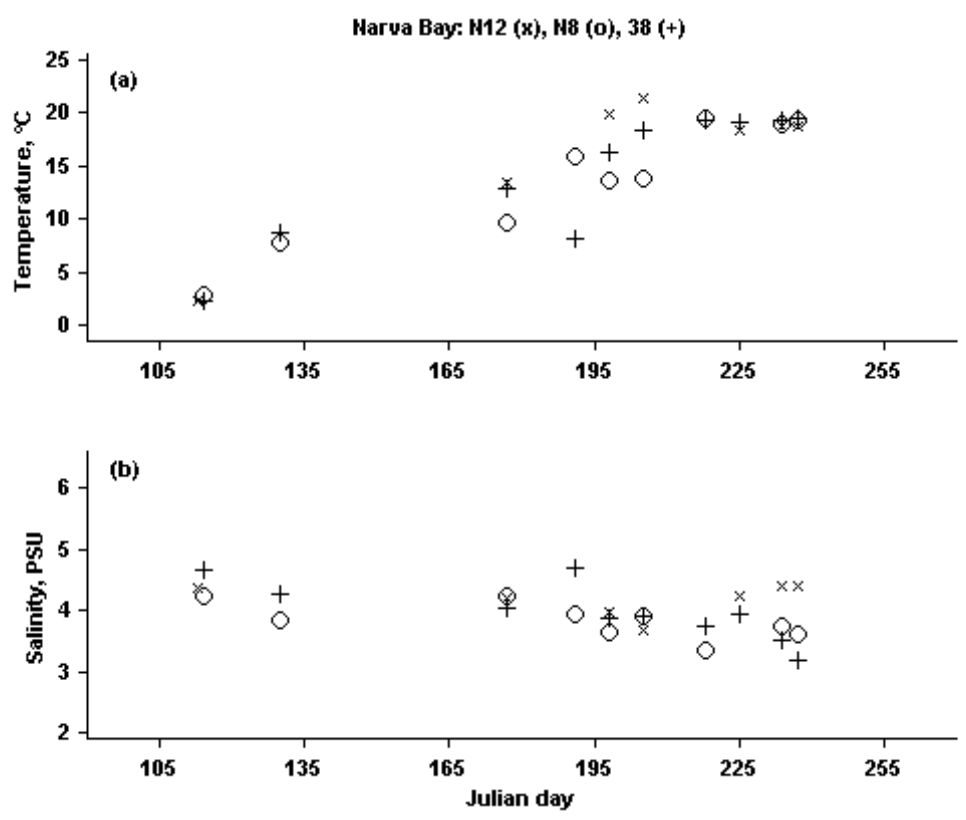

Fig. 7. The $10 \mathrm{~m}$ depth (or until bottom at the shallow area) average temperature (a) and salinity (b) at stations N8, N12, and 38 during April-August 2001.

The observed stratification changes indicate the presence of complicated mixing processes which influenced the upper-layer characteristics in the Narva Bay, and that the water buoyancy was rather independently related to salinity and temperature.

\section{SURFACE-LAYER CURRENTS}

The Narva Bay currents were observed at the POI1 and POI2 sites shown in Fig. 1, where the current meters were moored in the surface layer. The water depths at the buoy stations were around 20 and $40 \mathrm{~m}$, respectively. The current velocity was recorded with a 10-minute interval, which represents rather highresolution data for studying the low-frequency motion in the coastal and open-sea sides of the bay.

In the vicinity of Narva-Jõesuu, measurements were performed during 4-18 July and 25 July-28 August. A current meter was deployed at the depth of $5 \mathrm{~m}$. The average current speed for the entire measurement period was $7.1 \mathrm{~cm} \mathrm{~s}^{-1}$. The current speed maximum was $30.2 \mathrm{~cm} \mathrm{~s}^{-1}$, whereas during the observational periods, the current with the speeds over $20 \mathrm{~cm} \mathrm{~s}^{-1}$ was seldom. The buoy at the station POI1 was located in the shallow area and the dominating current was oriented along the coastal contour (isobaths), but also the near-inertial fluctuations were apparent. The POI1 current, in principle, should characterize the 
spreading of the Narva River water in the bay, since the relatively light water forms the plume in the surface layer.

At the POI2 site during the period from 18 July until 28 August, the current was recorded at the depth of $7 \mathrm{~m}$. The average current speed was $11.3 \mathrm{~cm} \mathrm{~s}^{-1}$, but the flow fluctuations exceeded occasionally the value of $35 \mathrm{~cm} \mathrm{~s}^{-1}$. The comparatively strong current characterized the surface-layer motion in the opensea side of the bay since its velocity was quite frequently larger than $20 \mathrm{~cm} \mathrm{~s}^{-1}$. The growth of the near-inertial oscillations was evident during the stronger wind events. The buoy station was located far offshore and the effects of the bay boundaries on the surface-water motion were less important than at the POI1 station. A mean component of the observed flow at POI2 was directed eastward, which corresponds well to the long-term circulation scheme in the surface layer of the Gulf of Finland $\left[{ }^{10}\right]$.

By investigating the cumulative water motion in the Narva Bay, it is useful to construct progressive-vector diagrams for the observed currents. (A single measured current-vector actually represents average water motion during a short period; in our case it was 10 minutes, and if they are summarized in a way that each vector starts from the end of the previous vector in the progression of time, the resulting curve represents approximately the horizontal trajectory of the water parcel.) The results of calculations are shown in Fig. 8, where the measurements at stations POI1 and POI2 are used. In Fig. 8, the ordinate is directed to the north and
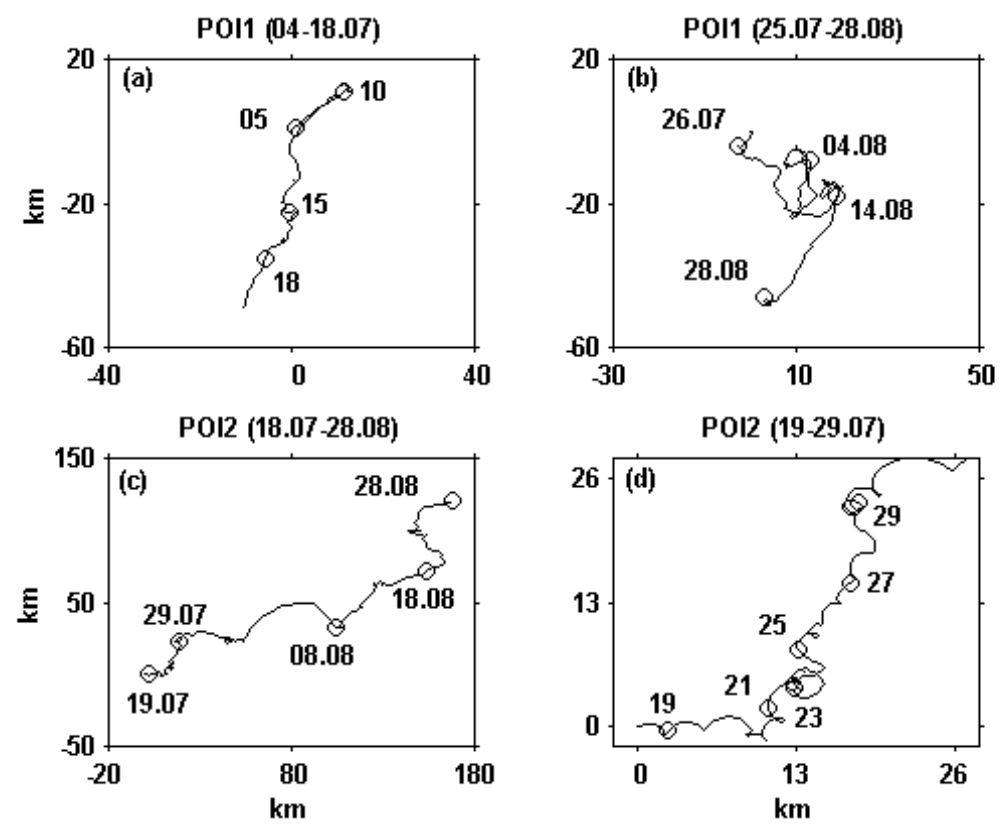

Fig. 8. Progressive-vector diagrams of the currents: (a) POI1 at $5 \mathrm{~m}$ depth, 4-18 July; (b) POI1 at $5 \mathrm{~m}$ depth, 25 July-28 August; (c) POI2 at $7 \mathrm{~m}$ depth, 18 July-28 August; (d) POI2 at $7 \mathrm{~m}$ depth, 19-29 July. 
the abscissa to the east, corresponding to the geographical coordinate system. (Cancelling artificial water drift in the calculus associated with the current meter "default" position in "quiescent sea", the velocity values $1.15 \mathrm{~cm} \mathrm{~s}^{-1}$ were zeroed.)

The progressive-vector curves in Fig. 8 allow us to relate the surface-water motion to the wind. For instance, the eastern winds existed in Narva-Jõesuu during 24-26 July, which changed to stronger SW winds on the 1-3 August as it was pointed out in Section 2. This atmospheric forcing situation apparently creates a quasi-steady northward current at the POI1 site, with the speed up to $15 \mathrm{~cm} \mathrm{~s}^{-1}$ (Fig. 8b). This particular example shows that the Ekman transport of the surface water can also magnify the spreading of the river water into the Narva Bay interior. Figure 8c, which represents the current at POI2 site, shows that the average flow is mainly directed eastward, but also the low-frequency oscillations are evident. Figure 8d, where the cumulative motion at POI2 is zoomed for a period between 19 and 29 July, shows how the southern wind on 19-20 July (as observed in Kunda, Table 1) created the corresponding near-inertial motion. The generation of the inertial oscillations by wind is not simple, since the changing stress at the surface can increase or decrease the amplitude of the sheared water motion in the sea.

\section{WIND-GENERATED MOTION}

The changing wind induces the unsteady Ekman transport, which affects the existing motion in the ocean. The wind-generated oscillations of the near-inertial period are usually confined into a comparatively thin surface layer $\left[{ }^{11}\right]$. The depth of the upper mixed layer in the Baltic Sea varies a great deal, stretching usually over $10 \mathrm{~m}$ in the open-sea area. The vertically integrated Ekman equations are given by

$$
\begin{aligned}
& \frac{\partial U}{\partial t}=f V+\frac{\tau_{x s}}{\rho}-\gamma U, \\
& \frac{\partial V}{\partial t}=-f U+\frac{\tau_{y s}}{\rho}-\gamma V,
\end{aligned}
$$

where the volume-transport variables along $x$ and $y$ axis (corresponding to the eastern and the northern direction, respectively), are

$$
(U, V)=\int_{-H}^{0}(u, v) d z,
$$

and $H$ is the depth of the mixed layer.

In Eqs. (1) and (2) $f$ is the Coriolis parameter, $\rho$ is the water density, and $\gamma$ is the Rayleigh friction parameter. The wind stress components can be estimated from 


$$
\left(\tau_{x s}, \tau_{y s}\right)=-\rho_{\mathrm{a}} C_{\mathrm{D}} W^{2}\left(\cos \left(90^{\circ}-\varphi\right), \sin \left(90^{\circ}-\varphi\right)\right),
$$

where $\rho_{\mathrm{a}}$ is the air density, $W$ is the wind speed, $\varphi$ is the angle of wind direction in the geographical coordinates, and $C_{\mathrm{D}}$ is the quadratic drag coefficient. We have assumed that the water density is uniform through the integrated layer. Thus, the inertial frequency $f$ is the only natural frequency of the model $\left[{ }^{12}\right]$. Note that the loss of momentum from the surface layer according to Eqs. (1), (2) is possible not only because of the wind stress acting opposite to the current but also due to different dissipation effects $\left[{ }^{13}\right]$. The analytical solution to the Ekman problem for $\gamma=0$ is well known (cf. Fredholm's problem in $\left.\left[{ }^{14}\right]\right)$. We solve the governing equation iteratively, using an explicit one-step numerical scheme, similar to the forward Euler method $\left[{ }^{15}\right]$.

The observed surface-layer current at POI2 site provides us with a good example of the near-inertial fluctuations during the period between 19 July and 3 August. Before we started calculations, first, the Kunda wind series interval was diminished from $3 \mathrm{~h}$ to $10 \mathrm{~min}$ by using the cubic-spline algorithm. The constants of the model were chosen as follows: $\rho_{\mathrm{a}}=1.22 \mathrm{~kg} \mathrm{~m}^{-3}$, $\rho=1 \times 10^{3} \mathrm{~kg} \mathrm{~m}^{-3}$, and $C_{\mathrm{D}}=1.2 \times 10^{-3}\left[^{16}\right]$. The surface water in the open-sea side of the bay was well mixed since during the observations the layer was homogeneous, the thickness of which varied between 10 and $21 \mathrm{~m}$. The westeast and south-north components of the Kunda wind stress $\left(\tau_{x s}, \tau_{y s}\right)$, the observed current $(u, v)$ and the calculated mean current $(U / H, V / H)$ are shown in Figs. 9 and 10. In the calculation, the mixed-layer depth equal to $15 \mathrm{~m}$ was

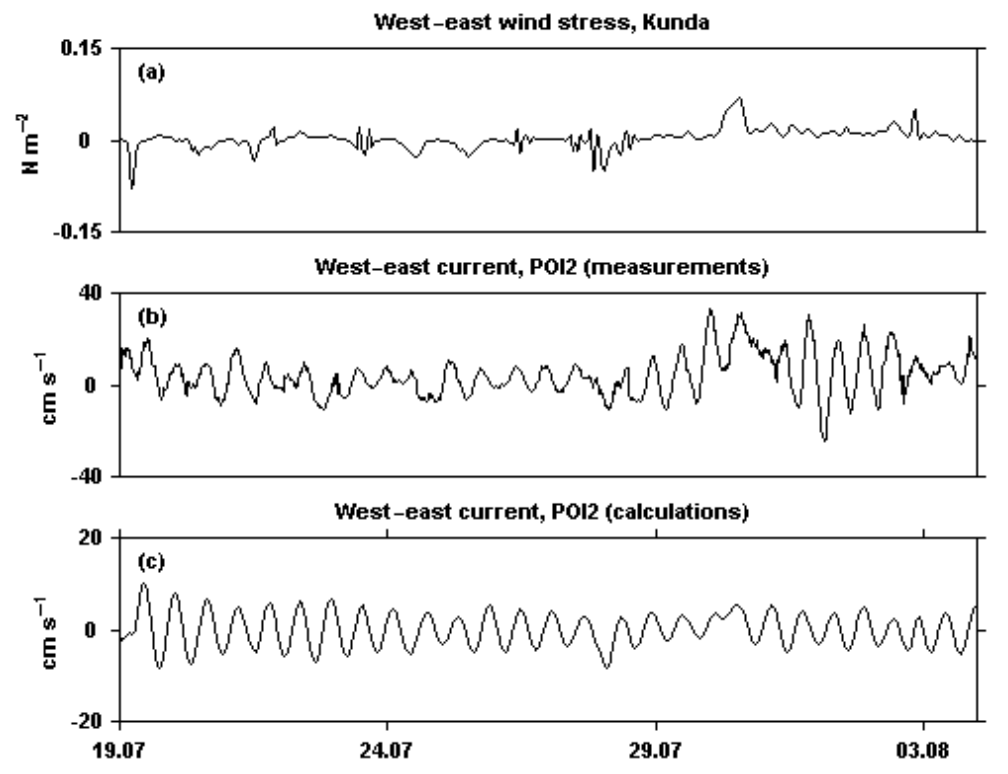

Fig. 9. West-east component of the Kunda wind stress (a), the observed POI2 current (b), and the calculated mean current (c). 

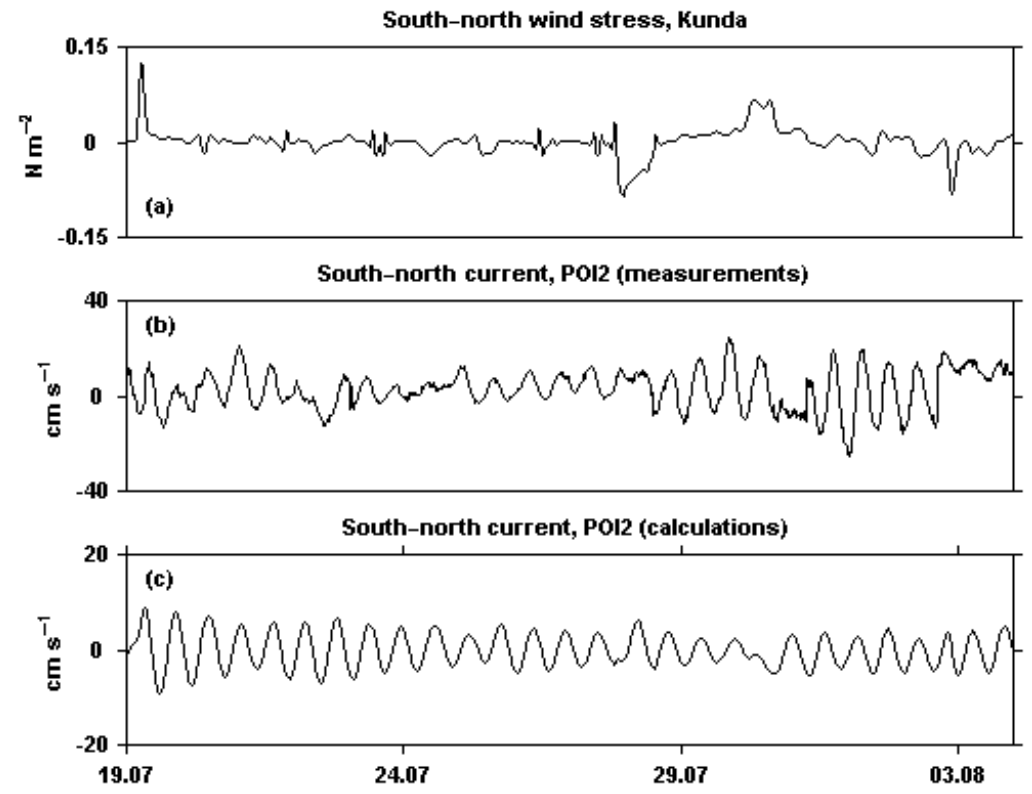

Fig. 10. South-north component of the Kunda wind stress (a), the observed POI2 current (b), and the calculated mean current (c).

used. On the basis of the measurements, the $e$-folding time was estimated to be $\gamma^{-1}=1.5$ days. It can be seen from Figs. 9 and 10 that the observed and modelled oscillations are sometimes drifted out of phase, but strong winds remove the phase difference. Illustrative examples are presented for the second half of July, when strong wind was present in Kunda (Table 1). However, the amplitude of the observed flow exceeded the average current from the model volume-transport estimate. (Strong or moderate winds around $2-3 \mathrm{~m} \mathrm{~s}^{-1}$, stronger than those observed in Kunda, would yield the amplitude of mean calculated current comparable to the amplitude of the observed current in Figs. 9 and 10.) The very slowly changing motion at POI2 site was not driven by the wind, and that is the main reason why there is apparent difference between the observed flow and the modelled current.

However, only the comparatively rapid phase changes of the current can be explained by the strong winds of short duration. The near-inertial fluctuations at POI1 site had a relatively weak amplitude. Probably an adjustment to the topography occurred, which explains the large drag (the $e$-folding time was around 0.5 days for the station site). The Narva River water intrusion also influenced the surface water stratification in POI1 site, since the CTD measurements revealed existence of a mixed layer only in July, the depth of which varied between 4 and $6 \mathrm{~m}$. We can conclude that the inertial oscillations are predominantly generated locally in the sea and the coastal winds represent only approximate forcing conditions for such motions. 


\section{CONCLUSIONS AND DISCUSSION}

The thermohaline fields and currents observed during April-August 2001 showed different water mass transformation processes in the Narva Bay. The Narva River inflow changed significantly water stratification only near the rivermouth area. The coastal-water characteristics and the mixed-layer depth in the bay were also related to the atmospheric forcing. Wind measurements at the coast of NE Estonia made it possible to investigate the forcing conditions. However, a problem that pertains to the available winds is associated with the observation place, since "roughness" of the coastal area certainly changed the wind speed as well as direction. Evidently the open-sea winds should be comparatively stronger than those that are observed at the coast $\left[^{5}\right]$. In the western side of the bay, the moderate winds with a duration around two days explained well the surface water flows associated with the Ekman transport, which in some cases led to large vertical displacements of the coastal waters. But near the river-mouth area, such winds were too weak or short to allow the deep water to reach the surface.

The hydrophysical measurements revealed an upwelling close to the Sillamäe shore in July. This upwelling was not a purely local response to the wind since the water along most of the bay coast was rather homogeneous, but only the water close to the river-mouth area saved the stratification. The characteristics of the Narva Bay surface layer were investigated using the CTD measurements. The upper water was well mixed in the open-sea side of the bay, but near the shore the mixed layer had quite variable, occasionally even vanishing, depth. The hydrographic measurements revealed that in the early spring, the salinity determined the density stratification in the bay, and in summer, the thermocline separated the surface layer from the deep water.

The surface-layer currents in the Narva Bay during July-August 2001 were dependent on the strong and moderate winds. At the buoy station near the shore, the cumulative water motion was predominantly along the coastal contour and owing to the vicinity of the river-mouth, this current characterized the freshwater spreading. At the buoy station offshore, the mean flow was mainly eastward. The near-inertial oscillations were apparent in the open sea as well as in the coastal areas, having larger amplitude offshore. (A good example of the inertial oscillations in the southern Baltic is provided in $\left.\left[{ }^{17}\right]\right)$. The near-inertial current in the surface layer grows to a large amplitude with a storm passing, and then decays slowly in the ocean $\left[{ }^{6}\right]$. The weather during the summer 2001 was relatively calm and, thus, the wind-energy transfer to the different motions in the bay, associated also with low-frequency oscillations, was related to the stratification. An apparent decrease in the vertical temperature gradient occurred in August, when the deep-water temperature increased considerably in the deep layer, approximately for $10-15^{\circ} \mathrm{C}$. For example, in the bays of Tagalaht and Uudepanga, the water was not stratified at all in late autumn 2000 and the nearinertial oscillations were extremely weak $\left[{ }^{18}\right]$. 
Finally, the relationships between the winds and the current anomalies were proved within the framework of the integrated Ekman equations. The phase variation of the locally generated oscillating current was comparatively well reproduced at the POI2 site. However, the simulation of the observed growth of the oscillations amplitude was not so successful. The reason can be a varying wind field, which affected the depth of the mixed layer. Also, the roughness of the coastal area changed the wind characteristics and added inaccuracies to the surface stress estimate. The unsteady Ekman transport in the Narva Bay was dependent on the strong winds blowing shortly in one direction, as compared to the inertial period of $14 \mathrm{~h}$. However, the wind-induced shared motion in the sea was associated with the mixing, which itself provides the depth-averaging of the surface current. In spite of uncertainties within the observations and approximations in the modelling, we conclude that the strong winds explain a great part of the currents variability observed in the mixed surface layer of the Narva Bay.

\section{ACKNOWLEDGEMENTS}

This work was financed by the Estonian Marine Institute through the Narva Bay contract and the Ministry of Environment within the framework of the National Monitoring Program. The authors appreciate valuable contribution by Inga Kanoshina, Kaire Kaljurand, Georg Martin, Arno Põllumäe, Andres Laanes, and Lauri London. We are thankful to captains Ringo Liepkalns, Henn Kuum, and Argo Korjus from the Estonian Maritime Academy and to the crews of the Estonian Maritime Board vessel EVA 308 (Tallinn) and the Estonian Borderguard vessel RVK 001 (Narva). We thank Tarmo Soomere and Tiit Koppel for their helpful comments during the preparation of the manuscript and the reviewers for their constructive suggestions.

\section{REFERENCES}

1. Protasjeva, M. and Eipre, T. Resources of the Surface Water of the UUSR. Baltic Region. Estonia. Gidrometeoizdat, Leningrad, 1972 (in Russian).

2. Mägi, L. and Lips, U. Budget components of water, salt, and nutrients in the Gulf of Riga in 1993-95. Proc. Estonian Acad. Sci. Biol. Ecol., 1998, 47, 14-31.

3. Cederlöf, U., Rodhe, J., Rydberg, L., and Shelstedt, P. Performance study of the Haamer gelatin pendulum current meter. J. Sea Res., 1996, 35, 55-61.

4. Karing, P. Õhutemperatuur Eestis. Eesti Geograafia Selts, Tallinn, 1992.

5. Soomere, T. and Keevallik, S. Anisotropy of moderate and strong winds in the Baltic Proper. Proc. Estonian Acad. Sci. Eng., 2001, 7, 35-49.

6. Käse, R. H. and Olbers, D. J. Wind-driven inertial waves observed during phase III of GATE. Deep-Sea Res., 1979, 22, 191-216.

7. Csanady, G. T. Circulation induced by river inflow in well mixed water over a sloping continental shelf. J. Phys. Oceanogr., 1984, 14, 1703-1711.

8. Bennett, J. R. A theory of large-amplitude Kelvin waves. J. Phys. Oceanogr., 1973, 3, 57-60.

9. Gill, A. E. and Clarke, A. J. Wind-induced upwelling, coastal currents, and sea-level changes. Deep-Sea Res., 1974, 21, 325-345. 
10. Elken, J. (Ed.). Deep water overflow, circulation and vertical exchange in the Baltic Proper. Estonian Marine Institute Report Series, 1996, 6, 1-91.

11. Pollard, R. T. On the generation by winds of inertial waves in the ocean. Deep-Sea Res., 1970, 17, 795-812.

12. Käse, R. H. Calculations of the energy transfer by the wind to near-inertial waves. Deep-Sea Res., 1979, 26, 227-232.

13. Pollard, R. T. and Millard, R. C. Comparison between observed and simulated wind-generated inertial oscillations. Deep-Sea Res., 1970, 17, 813-821.

14. Krauss, W. Methods and Results of Theoretical Oceanography I, Dynamics of the Homogeneous and the Quasihomogeneous Ocean. Gebrüder Bornträger, Berlin, 1973.

15. Vreugdenhil, C.B. Numerical Methods for Shallow-water Models. Kluwer, Dordrecht, 1994.

16. Otsmann, M., Astok, V., and Suursaar, Ü. A model for water exchange between the Baltic Sea and the Gulf of Riga. Nord. Hydrol., 1997, 28, 351-364.

17. Gustafson, T. and Kullenberg, B. Trägheitsströmungen in der Ostsee. Göteborgs K. Vet. Vitt.Samh. Handl., Femte Följden, 1933, 3, 1-7.

18. Kõuts, T. and Laanearu, J. Variability of currents in bays of Tagalaht and Uudepanga. Proc. Estonian Acad. Sci. Eng., 2001, 7, 126-140.

\title{
Termohaliinsete väljade muutlikkus ja madalsageduslikud hoovused Narva lahes
}

\author{
Janek Laanearu ja Urmas Lips
}

Narva lahe hüdrofüüsikalisi mõõtmisandmeid on kasutatud vee termodünaamiliste omaduste ja hoovuste kirjeldamiseks ajavahemikus aprillist augustini 2001. Lahe 14 mõõtejaamas jälgiti temperatuuri ja soolsust ning kahes poijaamas hoovuseid. Mõõtmisaparatuurina kasutati SeaBirdi CTD-sondi SeaCat ja Aanderaa hoovusmõõtjaid RCM-7. Narva-Jõesuu ja Kunda meteojaamas registreeriti aprillist augustini suhteliselt tugevaid kirdetuuli $\left(>7 \mathrm{~m} \mathrm{~s}^{-1}\right)$, kuid esines ka mõõdukaid (5-7 $\mathrm{m} \mathrm{s}^{-1}$ ) lõuna- ja läänekaarte tuuli. CTD profiilide põhjal on koostatud termohaliinsete väljade lõiked ja kaardid ning hoovusandmetest on konstrueeritud progressiivvektori diagrammid. Mõõtmisandmete analüüs võimaldas selgitada tuulest, rannikust ja avamere hoovustest tingitud tsirkulatsiooni Narva lahes. Kinnitust leidis ka Narva jõe vee mõju merelahe veemassi kihistumisele rannikutsoonis. Sillamäe šelfil registreeriti juulis süvavee tõus, mida seletab tugeva kagutuulega tekkiv Ekmani hoovus. Hoovusandmete aegridades esines madalsagedusliku võnkumise signaal, mille amplituud ja faas järgisid tugevate tuulte puhanguid. Mittestatsionaarne Ekmani koguvoolu hoovus seletab registreeritud inertssageduse lähedase hoovuse komponendi esinemist Narva lahe ülemises segunenud kihis. Vertikaalselt läbi selle kihi integreeritud Ekmani võrrandite numbriline lahend, mis arvestas tuulepinget ja ka Rayleigh' hõordumist, kirjeldas hästi hoovuse suuna muutust avamere poijaamas suve esimesel poolel. 